\title{
Belajar dari KKN Kebencanaan: Pola Distribusian Bantuan Paska Gempa Lombok antara MDMC dan BPBD
}

\author{
Joni Safaat Adiansyah', Bedy Aga Fara Matrani² \\ 1,2 Fakultas Teknik, Universitas Muhammadiyah Mataram \\ Email : joni.adiansyah@ummat.ac.id ${ }^{1}$, bedyfara@gmail.com² \\ *Corresponding author: joni.adiansyah@ummat.ac.id ${ }^{1}$
}

\begin{abstract}
ABSTRAK
Indonesia adalah salah satu negara yang memiliki berbagai macam potensi bencana seperti gempa bumi. Salah satu kejadian gempa bumi dengan kekuatan yang mencapai 6,8 Skala Richter (SR) terjadi di pulau Lombok Provinsi Nusa Tenggara Barat (NTB). Tujuan penulisan artikel ini adalah untuk memberikan gambaran terhadap pola distribusi bantuan kebencanaan yang efektif. Komponen penting yang sangat berperan dalam manajemen bencana adalah distribusi bantuan paska bencana. Program Pengabdian Masyarakat (PKM) dengan tema kebencanaan diinisiasi oleh Universitas Muhammadiyah Mataram. Sejumlah 30 mahasiswa dikirim untuk membantu program distribusi bantuan paska gempa di dua simpul pengelolaan bantuan yaitu Muhammadiyah Managament Disaster Center (MDMC) yang bertempat di Gedung Dakwah Pengurus Wilayah Muhammadiyah (PWM) NTB dan Badan Penanggulangan Bencana Daerah (BPBD) yang bertempat di kantor BPBD NTB. Dari kegiatan ini disimpulkan bahwa tata kelola dan strategi dalam pengelolaan distribusi bantuan bencana yang dilakukan oleh MDMC dan BPBD memiliki karakteristik yang berbeda, hal ini terkait dengan 'payung' operasional yang diacu oleh kedua lembaga tersebut. Beberapa karateristik perbedaan tersebut adalah sumber dana, sistim koordinasi, dan sumberdaya yang pada akhirnya menghasilkan perbedaan dalam alur distribusi.
\end{abstract}

Kata Kunci: Bencana; BPBD; Distribusi Bantuan; MDMC; Paska Gempa

\begin{abstract}
Indonesia is one the countries that has various potential disasters such as the Earth Quake. One of the Earth Quakes that reached magnitude of 6.8 Richter Scale (SR) was occurred at Lombok Island Province of West Nusa Tenggara (NTB). A critical component that plays in the disaster management is humanitarian logistic supply. The community services program (PKM) with disaster theme was initiated by Universitas Muhammadiyah Mataram. Total of 30 students were sent for assisting the humanitarian logistic supply post-earth quake at two main distribution focal point, namely Muhammadiyah Disaster Management Centre that located at Gedung Dakwah Pengurus Wilayah Muhammadiyah (PWM) NTB, and The Provincial Disaster Management Office (BPBD) that located at BPBD NTB office. The PKM concluded that the distribution of humanitarian logistic by MDMC and $B P B D$ has different characteristic associated with management and strategy, these differences occurred due to operational guideline that referred by those two institution. Some of the characteristic differences include funding resource, coordination system, and human resources that generated the different distribution flow.
\end{abstract}

Keywords: Disaster; BPBD; Distribution Aid; MDMC; Post Earth Quake 


\section{PENDAHULUAN}

Indonesia berada di daerah yang rawan bencana sehingga istilah 'ring of fire' sering digunakan untuk menggambarkan besarnya potensi kebencanaan untuk wilayah Indonesia. Bencana yang tejadi di Indonesia sangat beragam antara lain banjir, tanah longsor, abrasi, gempa bumi, tsunami dan letusan gunung berapi. Dari data Badan Nasional Penanggulangan Bencana (BNPB) terlihat bahwa tren kejadian bencana di Indonesia mengalami fluktuasi dimana kejadian bencana terbanyak tercatat di Tahun 2017 dengan total hampir mencapai 3.000 kejadian seperti yang ditampilkan pada Gambar 1. Fluktuasi kejadian mengalami penurunan cukup signifikan pada Tahun 2018 dimana total kejadian sekitar 1.134 kejadian.

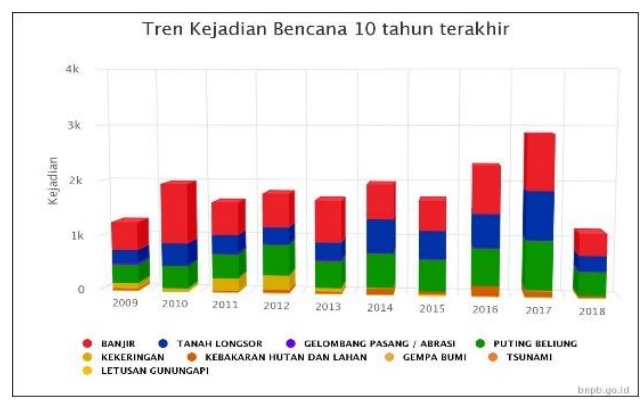

Gambar 1: Tren Kejadian Bencana Periode 2009-2018 (BNPB, 2018) Sumber: http://dibi.bnpb.go.id/dibi/

Jika melihat sebaran kejadian bencana yang terjadi pada Periode 2009-2018 maka pulau Jawa khususnya Jawa Tengah menempati jumlah kejadian terbanyak seperti yang ditampilkan pada Gambar 2. Dominasi kejadian bencana terbanyak adalah banjir kemudian diikuti dengan puting beliung dan gelombang pasang/abrasi.

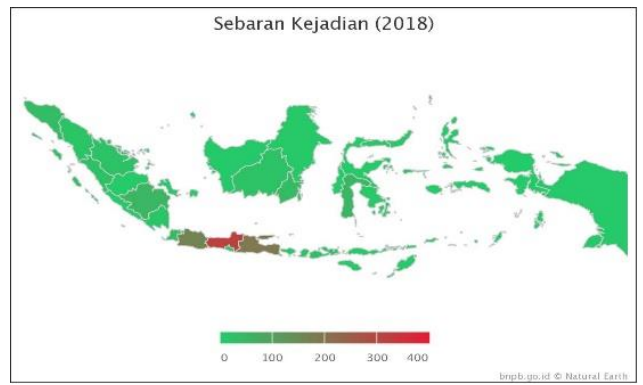

Gambar 1: Sebaran Bencana Periode 2009-2018 (BNPB, 2018)

Sumber: http://dibi.bnpb.go.id/dibi/

Terkait dengan kejadian bencana maka Provinsi Nusa Tenggara Barat (NTB) juga merupakan daerah yang tidak terlepas dari bencana baik berupa banjir, gelombang pasang/abrasi, maupun letusan gunung api. Salah satu jenis bencana yang terjadi di Provinsi NTB adalah gempa bumi yang diakibatkan oleh pergeseran lempeng. Dari sebaran intensitas gempa yang tercatat oleh USGS (Gambar 3) terlihat bahwa sebaran paling banyak berada di pulau Lombok bagian utara dengan skala yang bervariasi $3 \mathrm{SR}-7 \mathrm{SR}$.

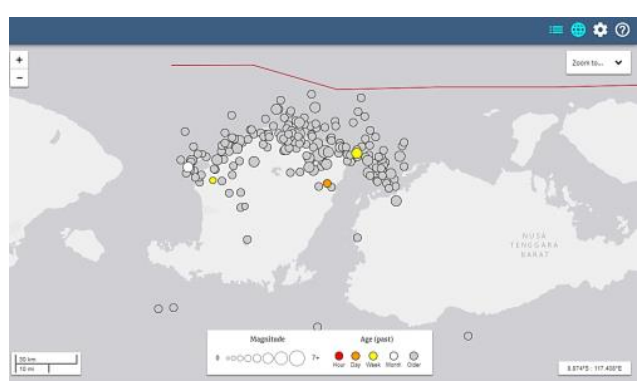

Gambar 2: Sebaran Gempa di Pulau Lombok (USGS, 2018)

Sumber: https://earthquake.usgs.gov/earthquakes/map/ 
Dari histori yang dicatat oleh Pusat Vulkanologi dan Mitigasi Bencana Geologi (PVMBG) bahwa gempa yang menimpa pulau Lonbok pada hari Minggu tanggal 5 Agustus 2018 adalah gempa terbesar dalam histori gempa di wilayah pulau Lombok. Adapun histori gempa di wilayah pulau Lombok sesuai dengan data PVMBG ditampilkan pada Tabel 1.

Tabel 1: Ringkasan Histori Gempa di Wilayah Pulau Lombok

$\begin{array}{cccc}\text { Tahun } & \begin{array}{c}\text { Kedalaman } \\ (\mathbf{K m})\end{array} & \begin{array}{c}\text { Lokasi } \\ \text { Koordinat } \\ (\mathbf{L S} / \mathrm{BT})\end{array} & \begin{array}{c}\text { Kekuatan } \\ (\mathrm{SR} / \mathrm{MMI})\end{array} \\ \mathbf{1 9 7 9} & 25 & 8,2^{\circ} \mathrm{LS} / & \mathrm{MMI} \text { VIII- } \\ & & 115,9^{\circ} \mathrm{BT} & \mathrm{IX} \\ \mathbf{2 0 0 4} & 33 & 8,4^{\circ} \mathrm{LS} / & 6,2 \mathrm{SR}- \\ & & 115,95^{\circ} \mathrm{BT} & \mathrm{MMI} \text { VI } \\ \mathbf{2 0 1 3} & 10 & 8,43^{\circ} \mathrm{LS} / & 5,4 \mathrm{SR}- \\ & & 116,04^{\circ} \mathrm{BT} & \mathrm{MMI} \text { VI }\end{array}$

Sumber: PVMBG, 2018

Gempa yang terjadi pada Tahun 2018 di NTB tidak saja menimbulkan kerugian harta benda tapi juga kehilangan jiwa sekitar 500 orang lebih yang utamanya akibat tertimpa bangunan. Kegiatan bantuan pasca gempa menjadi sesuatu yang sangat penting dilakukan untuk meringankan beban masyarakat yang terkena dampak gempa. Penyebaran logistic kemanusian (humanitarian logistic) adalah kegiatan wajib yang harus dilakukan oleh berbagai pihak dalam penanganan kejadian pasca gempa termasuk gempa Lombok. Tercatat lebih dari 10 lembaga penyalur logistic kemanusian, dimana dua diantaranya adalah Badan Penanggulangan Bencana Daerah (BPBD) Provinsi NTB dan
Muhammadiyah Disaster Management Center (MDMC). Kedua lembaga ini mempunyai perbedaan karakteristik terkait pengelolanya dimana BPBD dikelola oleh Pemerintah Daerah dan MDMC dikelola oleh Organisasi Persyarikatan Muhammadiyah. Perbedaan pengelola akan berimplikasi pada perbedaan sumber dana, perbedaan management pengelolaan termasuk sumberdaya manusia. Tujuan penulisan artikel ini adalah untuk memberikan gambaran terhadap pola distribusi bantuan kebencanaan yang efektif.

\section{METODE PENELITIAN}

Pelaksanaan Pengabdian Kepada Masyarakat (PKM) dilaksanakan bersamaan dengan pelaksanaan KKN Periode 1 Angkatan XXXII sehingga pelibatan mahasiswa menjadi unsur utama dalam pelaksanaan PKM ini. Metode yang digunakan dalam pelaksanaan PKM ini adalah pelibatan mahasiswa dan mitra dalam kaitannya dengan penyaluran bantuan bencana gempa di Lombok. Mahasiswa KKN yang tergabung ke dalam kelompok 31 diturunkan ke dua lokasi mitra yaitu Gedung Dakwah (MDMC) dan Kantor BPBD Provinsi NTB. Pelibatan mahasiswa dalam kapasitasnya sebagai relawan gempa Lombok untuk membantu pengaturan distribusi bantuan/logistik di bawah koordinasi MDMC dan BPBD Provinsi NTB. 
Untuk mengetahui alur pendistribusian bantuan paska gempa di MDMC dan BPBD, dilakukan observasi dan wawancana (interview). Observasi yang dilakukan di lokasi sentral logistik MDMC dan BPBD meliputi prosedur penerimaan, pemilahan, dan pendistribusian bantuan. Sedangkan wawancara melibatkan staf yang bertugas dan bertanggung jawab terhadap pendistribusian bantuan paska gempa. Wawancara dimaksudkan untuk mendapatkan informasi terkait dengan karakteristik pendistribusian bantuan kebencanaan.

Kegiatan dilakukan di sentral logistik MDMC yang bertempat di Gedung Dakwah Pengurus Wilayah (PWM) Nusa Tenggara Barat (ring road selatan Kota Mataram) dan sentral logistik BPBD di Kantor BPBD Provinsi Nusa Tenggara Barat (ring road selatan Kota Mataram).

Adapun detail tiga jenis kegiatan utama yang dilakukan yaitu:

- Pemilahan logistik bantuan: kegiatan ini bertujuan untuk memudahkan penyaluran bantuan dan menyesuaikan dengan kebutuhan masyarakat yang terkena dampak gempa.

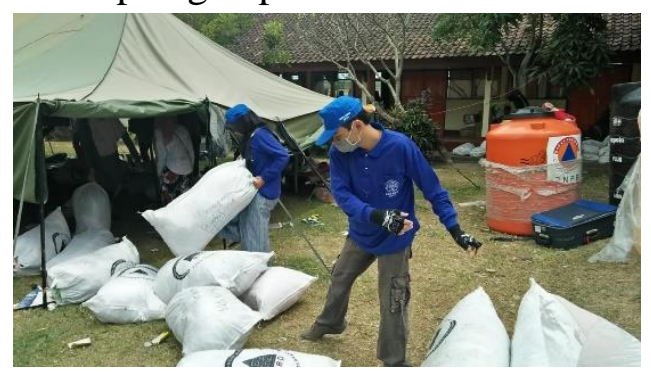

Gambar 4: Pemilahan Bantuan
- Pencatatan bantuan masuk ke posko dan keluar dari posko: kegiatan ini bertujuan untuk memastikan keseimbangan antara supply dan demand dari setiap item bantuan yang masuk ke posko. Kegiatan pencatatan hanya dibebankan pada posko MDMC sedangkan untuk posko BPBD NTB kegiatan ini sudah dilakukan oleh staf BPBD bidang logistik.

- Membantu penyaluran bantuan: kegiatan ini dilakukan baik secara langsung maupun mengikuti jadwal penyaluran yang sudah ditentukan oleh MDMC dan BPBD NTB.

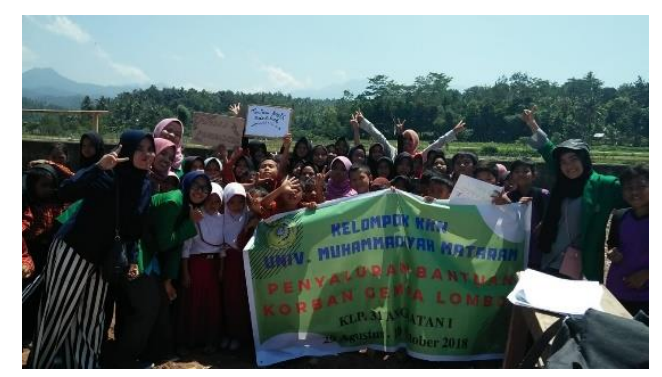

Gambar 5: Penyaluran Bantuan

\section{HASIL DAN PEMBAHASAN}

Penyaluran logistik dalam penanggulangan bencana biasanya dikenal dengan istilah humanitarian logistic. Berbagai tahapan terlibat di dalam kegiatan humanitarian logistic antara lain perencanaan, pelaksanaan, dan pengendalian aliran (flow) bantuan (Ahdi, 2015). Keterlibatan berbagai pemangku kepentingan sangat dibutuhkan agar penyaluran bantuan kemanusian bencana bisa dilakukan dengan cepat, efisien, tepat waktu dan tepat sasaran. Beberapa hambatan yang mungkin terjadi terkait dengan penyaluran logistik kemanusian antara lain struktural aparat pemerintahan yang kurang siap (SDM), akses jalan yang 
terputus (Arlianto, 2018). Selain itu kesiapan pemangku kepentingan lain antara lain swasta, Lembaga Swadaya Masyarakat (LSM) akan memberikan pengaruh terhadap kecepatan penyaluran logistik kemanusiaan.

Pengambilan keputusan untuk humanitarian logistic akan berbeda pada setiap tahapan seperti tahapan perencanaan akan fokus pada kriteria penyalur bantuan, namun saat bencana telah terjadi maka kecepatan pengiriman bantuan menjadi prioritas utama dalam pengambilan keputusan (Altay, et al., 2009) (Hadiguna \& Wibowo, 2012) (Prastyowati, 2013). Identifikasi terhadap tahapan penanganan humanitarian logistic tersebut termasuk di dalamnya kegiatan dan strategi yang digunakan ditampilkan pada Tabel 2.

Tabel 2: Tahapan dan Kegiatan untuk Humanitarian Logistic

\begin{tabular}{|c|c|c|}
\hline Tahapan & Kegiatan & Strategi \\
\hline \multirow{8}{*}{$\begin{array}{l}\text { Perencanaan } \\
\text { Strategis }\end{array}$} & $\begin{array}{l}\text { Menentukan kebutuhan } \\
\text { masyarakat }\end{array}$ & \multirow{8}{*}{$\begin{array}{l}\text { Pengelolaan } \\
\text { Rantai } \\
\text { Distribusi } \\
\text { (SCM) }\end{array}$} \\
\hline & $\begin{array}{l}\text { Memperikirakan kondisi } \\
\text { bencana (ketidakpastian, } \\
\text { kualitas informasi, } \\
\text { kompleksitas) }\end{array}$ & \\
\hline & $\begin{array}{l}\text { Mengembangkan rencana } \\
\text { kooordinasi }\end{array}$ & \\
\hline & $\begin{array}{l}\text { Memperbaiki komunikasi } \\
\text { (internal/eksternal) }\end{array}$ & \\
\hline & $\begin{array}{l}\text { Mempertimbangkan } \\
\text { rasionalisasi dasar } \\
\text { penyaluran }\end{array}$ & \\
\hline & $\begin{array}{l}\text { Mengatur kriteria seleksi } \\
\text { penyalur (vendor) }\end{array}$ & \\
\hline & $\begin{array}{l}\text { Membangun multi fungsi } \\
\text { tim }\end{array}$ & \\
\hline & $\begin{array}{l}\text { Mendorong kepercayaan } \\
\text { dan komitmen selama } \\
\text { proses penyaluran }\end{array}$ & \\
\hline \multirow[t]{4}{*}{ Persiapan } & Seleksi penyalur (vendor) & \multirow{4}{*}{$\begin{array}{l}\text { Stochastic } \\
\text { Optimisation }\end{array}$} \\
\hline & $\begin{array}{l}\text { Seleksi pendukung vendor } \\
\text { logistic }\end{array}$ & \\
\hline & $\begin{array}{l}\text { Seleksi lokasi gudang } \\
\text { penyimpanan }\end{array}$ & \\
\hline & Pengumpulan Data & \\
\hline
\end{tabular}

\begin{tabular}{|c|c|c|}
\hline Tahapan & Kegiatan & Strategi \\
\hline \multirow{5}{*}{$\begin{array}{l}\text { Respon } \\
\text { sebelum } \\
\text { kejadian } \\
\text { (pre-event) }\end{array}$} & $\begin{array}{l}\text { Pengumpulan Data terkait } \\
\text { kejadian }\end{array}$ & \multirow[t]{5}{*}{$\begin{array}{l}\text { Analisa } \\
\text { Keputusan }\end{array}$} \\
\hline & Rencana Evakuasi & \\
\hline & Rencana skema pembelian & \\
\hline & $\begin{array}{l}\text { Perubahan penyaluran di } \\
\text { antara gudang penyimpanan }\end{array}$ & \\
\hline & Rencana logistik & \\
\hline \multirow{3}{*}{$\begin{array}{l}\text { Respon } \\
\text { setelah } \\
\text { kejadian } \\
\text { (post-event) }\end{array}$} & $\begin{array}{l}\text { Pengumpulan Data terkait } \\
\text { kerusakan }\end{array}$ & \multirow{3}{*}{$\begin{array}{l}\text { Scheduling } \\
\text { and } \\
\text { Optimisation }\end{array}$} \\
\hline & $\begin{array}{l}\text { Kebutuhan dan Penyaluran } \\
\text { (demand and supply) di } \\
\text { lokasi, skala prioritas }\end{array}$ & \\
\hline & $\begin{array}{l}\text { Ketersediaan penyalur } \\
\text { bantuan dan kapasitasnya }\end{array}$ & \\
\hline
\end{tabular}

Kompleksitas dari tahapan penyaluran bantuan bencana memerlukan kesiapan sumberdaya baik manusia dan organisasi serta kesiapan regulasi untuk menunjang efektifitas kegiatan penyaluran bantuan (Purnomo \& Utomo, 2008). Hal tersebut akan memberikan dampak langsung terhadap kecepatan dan ketepatan penyaluran sehingga memberikan manfaat kepada korban bencana.

Pendistribusian bantuan bencana gempa di Lombok yang dilakukan oleh MDMC dan BPBD Provinsi NTB memiliki karakteristik dan perbedaan. Hal mendasar yang melatar belakangi pembedaaan ini adalah jenis organisasi dan sumber pendanaan. MDMC adalah sebuah organisasi yang dibentuk oleh PP Muhammadiyah dan berada di bawah pengawasan PP Muhammadiyah (Hilman, 2018). Sebagai organisasi kemasyarakatan maka pendanaan berasal dari PP Muhammadiyah yang sebagian besar dananya juga berasal dari para donator. Istilah donator disini bisa diartikan beragam antara lain Perguruan Tinggi 
Muhammadiyah/ Aisyiah (PTM/A), masyarakat umum, dan anggota persyarikatan baik individu maupun kelompok.

Terkait dengan penyelenggaraan bantuan logistik kemanusian (bencana) maka pola penyelenggaraan manajemen logistik dan peralatan melibatkan beberapa lembaga berdasarkan territorial wilayah yaitu MDMC PP Muhammadiyah, MDMC Wilayah (PWM) dan MDMC Daerah (PWM). Dengan pelibatan lembaga ini maka sistem pengelolaan akan menerapkan sistem manajemen sesuai fungsi lembaga, sistem komando, sistem operasi, sistem perencanaan, sistem administrasi dan keuangan, dan sistem komunikasi dan transportasi. Pola distribusi yang diterapkan oleh MDMC selama penanganan logistik paska gempa Lombok seperti ditampilkan pada Gambar 4.

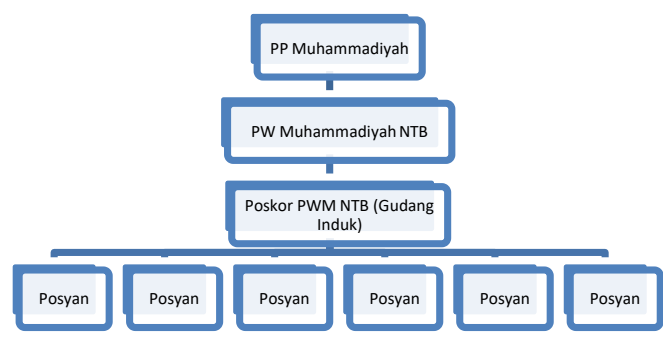

Gambar 4: Pola Distribusi MDMC

Sistim pembagian peran setiap tingkatan organisasi dalam distribusi bantuan paska gempa menghasilkan tugas dan tanggung jawab yang berbeda sebagai berikut: 1). Pimpinan Pusat Muhammadiyah

(PP) membawa peran koordinasi dengan lembaga dan majelis lain dalam organisasi Persyarikatan, 2).

Lembaga

Penanggulangan

Bencana Wilayah (PWM) bertugas sebagai penyelenggara manajemen logistik dan peralatan di wilayahnya seperti terlihat pada Gambar 5, titik kontak utama bagi operasional di area bencana, 3) Pusat Koordinasi (Poskor) berada dalam pengelolaan MDMC dimana kegiatan utama yang dilakukan adalah menerima dan melaksanakan manajemen logistik, koordinasi dengan posko-posko pelayanan (Posyan) yang berada langsung pada daerah terdampak gempa.

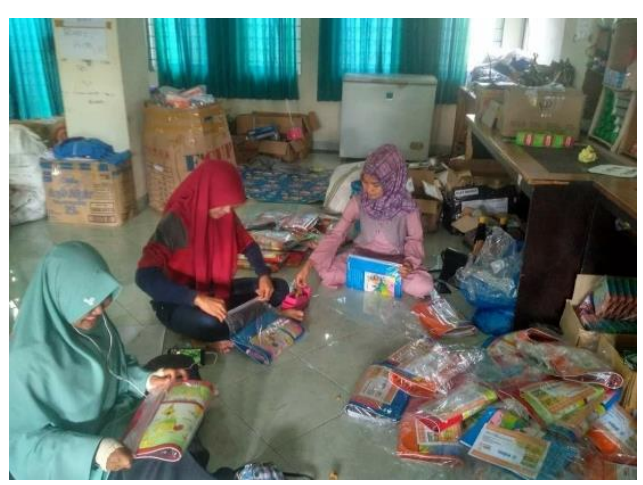

Gambar 5: Kegiatan MDMC di Posko Gedung Dakwah PWM

Badan Penanggulangan Bencana adalah lembaga pemerintah yang berada di tingkat Nasional dan Daerah. Pembentukan Badan Nasional Penanggulangan Bencana berdasarkan Undang-Undang Nomor 24 Tahun 2007 tentang Penanggulangan Bencana. Tugas yang diemban oleh lembaga ini adalah antara lain a). Memberikan 
pedoman dan pengarahan terhadap usaha penanggulangan bencana yang mencakup pencegahan bencana, penanganan tanggap darurat, rehabilitasi, dan rekonstruksi secara adil dan setara; b). Menetapkan standardisasi dan kebutuhan penyelenggaraan penanggulangan bencana berdasarkan Peraturan Perundang-undangan;

c).

Menyampaikan informasi kegiatan kepada masyarakat; d). Melaporkan penyelenggaraan penanggulangan bencana kepada Presiden setiap sebulan sekali dalam kondisi normal dan pada setiap saat dalam kondisi darurat bencana; e). Menggunakan dan mempertanggungjawabkan sumbangan/bantuan nasional dan internasional; f). Penggunaan anggaran yang diterima dari Anggaran Pendapatan dan Belanja Negara dipertanggung jawabkan; g). Melaksanakan kewajiban lain sesuai dengan Peraturan Perundangundangan; dan h). Menyusun pedoman pembentukan Badan Penanggulangan Bencana Daerah.

Bantuan logistik kebencanaan dilaksanakan dengan menganut pola penyelenggaraan yang melibatkan beberapa lembaga/instansi dalam sistem kelembagaan dalam berbagai wilayah yang dilaksanakan secara terpadu antara Nasional, Provinsi, dan Kabupaten / Kota. Pelaksanaan pengerahan bantuan logistik dari asal sampai dengan lokasi bencana dilaksanakan dibawah koordinasi / kendali Kepala BPBD Kabupaten/ Kota yang bersangkutan. Salah satu simpul distribusi adalah Kantor BPBD Provinsi Nusa Tenggara Barat (NTB) sebagai salah satu lokasi KKN Kebencanaan seperti ditunjukkan pada Gambar 6.

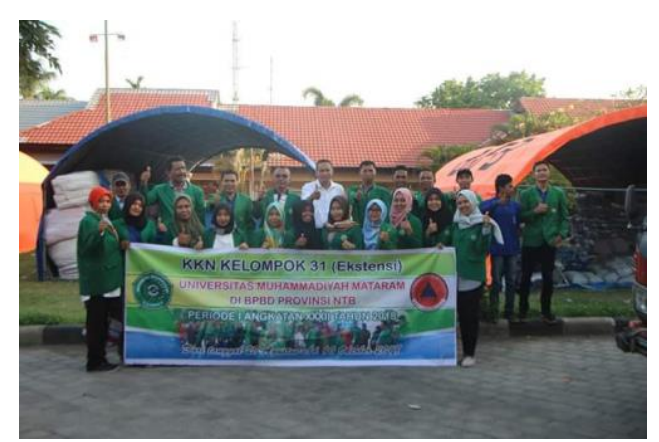

Gambar 6: KKN Kebencanaan Posko BPPD

\section{SIMPULAN}

Pengelolaan distribusi bantuan bencana gempa yang terjadi di Lombok Nusa Tenggara Barat dilakukan oleh Organisasi Pemerintah maupun Non-Pemerintah. Organisasi Pemerintah bearada dibawah koordinasi Badan Penanggulangan Bencana Daerah (BPBD) Provinsi Nusa Tenggara Barat. Sedangkan salah satu organisasi Non-Pemerintah yang aktif melakukan distribusi bantuan gempa di Lombok adalah Muhammadiyah Disaster Management Centre (MDMC) yang mengambil posko di Gedung Dakwah Pengurus Wilayah Muhammadiyah (PWM) Provinsi Nusa Tenggara Barat.

Tata kelola dan strategi dalam pengelolaan distribusi bantuan bencana yang dilakukan oleh MDMC dan BPBD memiliki karakteristik yang berbeda, hal ini terkait dengan 
'payung' operasional yang diacu oleh kedua lembaga tersebut. Beberapa karateristik perbendaan tersebut adalah sumber dana, sistim koordinasi, dan sumberdaya. Perbedaan karakteristik tersebut menghasilkan perbedaan dalam alur distribusi.

\section{DAFTAR PUSTAKA}

Ahdi, D., 2015. Perencanaan

Penanggulangan Bencana

Melalui Pendekatan

Manajemen Resiko.

Reformasi, 5(1), pp. 13-30.

Altay, N., Prasad, S. \&

Sounderpandian, J., 2009.

Strategic planning for disaster relief logistics:. Int. J.

Services Sciences.

Arlianto, 2018. Logistik

Kemanusiaan. Surabaya:

Universitas Surabaya.

BNPB, 2018. Sebaran Bencana 2009-2018. Jakarta: Badan

Nasional Penanggulangan

Bencana.

BNPB, 2018. Tren Kejadian

Bencana 2009-2018, Jakarta:

Badan Nasional

Penangulangan Bencana.

Hadiguna, R. A. \& Wibowo, A.,

2012. Simulasi Sistim

Logistik Bantuan Bencana

Gempa-Tsunami: Studi

Kasus di Kota Padang. Jurnal
Teknik Industri, 13(2), pp. 116-125.

Hilman, Y. A., 2018. Disaster Management Concept of Muhammadiyah Disaster Management Centre in Ponorogo, Indonesia. Otoritas: Jurnal Ilmu Pemerintahan, 8(1), pp. 6581.

Prastyowati, S., 2013. Sistem Penyaluran Bantuan Bencana Alam dan Keterpenuhan Kebutuhan Korban Kasus di Kabupaten Padang Pariaman. PKS, 12(2), pp. 80-92.

Purnomo, H. \& Utomo, H., 2008.

Keefektifan Kerjasama antar Lembaga dalam Operasi

Pemulihan terhadap Bencana Alam: Studi Empiris di Yogyakarta dan Jawa Tengah. Ekonomi dan Bisnis Indonesia, 23(4), pp. 404415.

USGS, 2018. Earth Quake

Distribution Map. s.1.:United State Geological Survey. 